\title{
Some Observations on the Dependence of Zooplankton Grazing on the Cell Size and Concentration of Phytoplankton Blooms*
}

\author{
T. R. Parsons, R. J. LeBrasseur and J. D. Fulton**
}

\begin{abstract}
The amount and the size fraction of particulate material consumed by different zooplankters were studied during the occurrence of two natural phytoplankton blooms. Both the size and quantity of particulate material eaten were determined with a Model B Coulter Counter. Results showed that a Chaetoceros bloom could be readily eaten by Euphausia pacifica but that Calanus pacificus, euphausiid furcilia and Pseudocalanus minutus were unable to derive more than a subsistence level of diet from the same plants. In contrast to the Chaetoceros bloom, a nanoplankter (ca $8 \mu$ diameter) was found to be less available as food for Euphausia pacifica but a better source of food for Calanus pacificus and euphausiid furcilia. These differences have been attributed to the physical availability of the food in terms of its size and shape.

Data on the feeding of zooplankton at different concentrations of phytoplankton were best explained by assuming a concentration dependent relationship similar to that proposed by IVLEY (1945) for planktivorous fish.
\end{abstract}

\section{Introduction}

There are a number of factors which may determine the suitability of a certain phytoplankter as food for a secondary producer. These factors can be divided into those which govern the availability of the food and those which describe the adequacy of the diet once food is available. In the latter case, PROVASOLI et al. (1959) have shown, for example, that although a zooplankter may eat a variety of foods, only certain types (or combinations) are a satisfactory diet for both growth and reproduction. Thus the adequacy of a phytoplankter as food for a secondary producer is largely a nutritional matter. In contrast, the initial availability of a food in situ must be determined to some degree by the size of the food particles and the concentration at which

* Received Oct. 24, 1966

Presented at the Eleventh Pacific Science Congress of the Pacific Science Association, held at the University of Tokyo, Japan, August-September 1966, and organized by the Science Council of Japan.

** Fisheries Research Board of Canada, Pacific Oceanographic Group, Nanaimo, B.C. they are present. WALNE (1965) has shown that oyster larvae perferentially assimilate very small flagellates, $2-3 \mu$ in diameter, while for larger herbivores there appears to be a perference for larger phytoplankters (MULLIN, 1963). Recent information on maximum and minimum food sizes for different zooplankters has been reviewed by J $\phi$ RGENSEN (1966).

The dependence of grazing on the concentration of prey has been described mathematically by IVlev (1945) and Cushing (1959). In the following discussion we have used a modification of IVLEV's equation to describe data obtained during a number of feeding experiments. IVLEV's original equation related ration $(r)$ to food density $(p)$ in the following manner:

$$
r=R\left(1-e^{-k p}\right)
$$

where $R$ is the maximum ration and $k$ is the proportionally constant. The curve represented by this equation passes through the origin which implies that animals continue feeding down to zero prey density. In fact it appeared from our observations that grazing occurred down to some low prey density, $p_{0}$, and then ceased. In order to accommodate this observation the above equation was modified to the form: 
Some Observations on the Dependence of Zooplankton Grazing on the Cell Size and Concentration of Phytoplankton Blooms

$$
r=R\left(1-e^{-k p} e^{k p_{0}}\right)
$$

In the following discussion, therefore, we have examined how size and concentration may affect the feeding of zooplankton on natural blooms of phytoplankton. In order to determine the size spectrum of food available in situ and the portion eaten, a new technique, involving an electronic particle analyser, has been introduced.

\section{Methods}

The following data were collected as part of a two month time series study carried out during June and July, 1966, from a barge anchored in Saanich Inlet, British Columbia. The inlet is a fjord located on the south east side of Vancouver Island and the hydrography of the area has been described by HERLINVEAUX (1962). By choosing a sampling location at some distance from the mouth of this inlet where the water column was not severely influenced by advective effects, it was possible to study the same zooplankton and phytoplankton populations over an extended period of time. Observations were further facilitated by being able to collect samples in the immediate vicinity of the barge, on which a laboratory had been set up to carry out experiments on natural populations. It was recognized that the disadvantage of the type of grazing experiment performed under these conditions, compared with grazing experiments in which cultures are employed, is that the state of natural blooms is never exactly the same from day to day, so that precise repetition of of experiments was impossible. However, a sufficient number of experiments were performed, particularly with the three size fractions of zooplankton grazing on two different sized phytoplankters as reported here, to give a clear indication of the extent of size and concentration dependence on feeding.

Samples of sea water for phytoplankton studies and zooplankton eggs were collected with 7 litre plastic Van Dorn bottles. Zooplankton samples for grazing experiments were collected by towing a net at less than 1 knot and at a depth where a particular group of zooplankters were known to occur. The zooplankton were further isolated into groups by gently netting or pipetting out unwanted organisms. This procedure lead to the selection of zooplankton according to size and in some cases a mixture of two species of approximately the same size were used in grazing experiments.

The size spectrum of suspended particulate material was determined using a Model B Coulter Counter fitted with 100 and $400 \mu$ apertures. The technical operation of this equipment for determining logarithmetic distributions of particle sizes has been described by SHELDON and PARSONS (1966a). In the following discussion all data are reported as the volume of particulate material in different size fractions of particle diameters. Although the instrument actually measures particle volume it should be understood that the particle diameter reported is that of a sphere with the same volume as the particle. Thus a chain forming phytoplankton species is recorded by the instrument as a unit volume for each chain. This volume occurs in the size spectrum of particle diameters as a volume having a diameter equivalent to a sphere of the same volume (for discussion see SHELDON and PARSONS, 1966b). In the case of the dimictic Chaetoceros bloom reported in this presentation, the unit volumes of the two species were sufficiently similar for the bloom to form a single biomass maximum in the spectra shown (e.g. Figure 2).

For grazing experiments at different concentrations of phytoplankton, a sample of seawater containing a phytoplankton bloom was collected and diluted with membrane filtered seawater to give successively smaller concentrations of phytoplankton. Equal numbers of a particular zooplankter were then added to each dilution of phytoplankton contained in $850 \mathrm{ml}$ mason jars. Control dilutions of phytoplankton to which no zooplankton were added were prepared at the same time and all samples were incubated in the dark for periods of 8 to 24 hours. The exact length of the incubation was decided on the assumption that zooplankton which migrated into the euphotic zone at night only fed during the 8 hours of darkness, while those that were located in the euphotic zone throughout the day fed continuously. Thus it was hoped that the feeding period in both cases represented the animals' daily food intake. 
The size spectrum of particulate material for each dilution of naturally occurring phytoplankton (with and without zooplankton) was measured at the end of the incubation and the decrease in the quantity of material in a particular size range was taken as the biomass of material grazed at that dilution. Because of the uncertainty of determining exact volumes and wet weights of the zooplankton, relationships used in this text involving the quantity of plant eaten as a percentage of animal biomass, have been expressed as carbon: carbon ratios. The zooplankton carbons were obtained as an average of several determinations by direct combustion of whole animals in a Coleman carbon analyser. The Coulter Counter particle volumes were converted to carbon using a facter of 0.052. This factor was obtained from a regression equation (SHELDON and PARSONS, 1966b) which was derived from more than 70 particulate carbon determinations and total Coulter Counter volumes, using particulate material collected during the same period as the experiments represented here. By making use of this factor for converting volumes measured with the Coulter Counter to milligrams of carbon, the question of the density of the particulate material and what conversion factors should be employed for wet to dry weight, and dry weight to carbon, are avoided.

\section{Results}

During the study period a major microphytoplankton bloom, consisting of a mixture of Chaetoceros socialis and Chaetoceros debilis, occurred and persisted for approximately three weeks in June. An earlier bloom consisting of Distephanus sp. was present briefly at the beginning of the study period, and a nanoplankton bloom, consisting of an unidentified $\mu$-flagellate, occurred during the third week of July. These blooms are recorded in Figure 1C as changes in Chlorophyll $a / \mathrm{m}^{3}$, expressed as an average value for six depths between 0 and $30 \mathrm{~m}$. Coincident with the Chaetoceros bloom was the appearance of a maximum biomass of euphausiid eggs (Figure 1A), and a considerably smaller biomass of copepod eggs (Figure 1B). In contrast to these levels of egg production

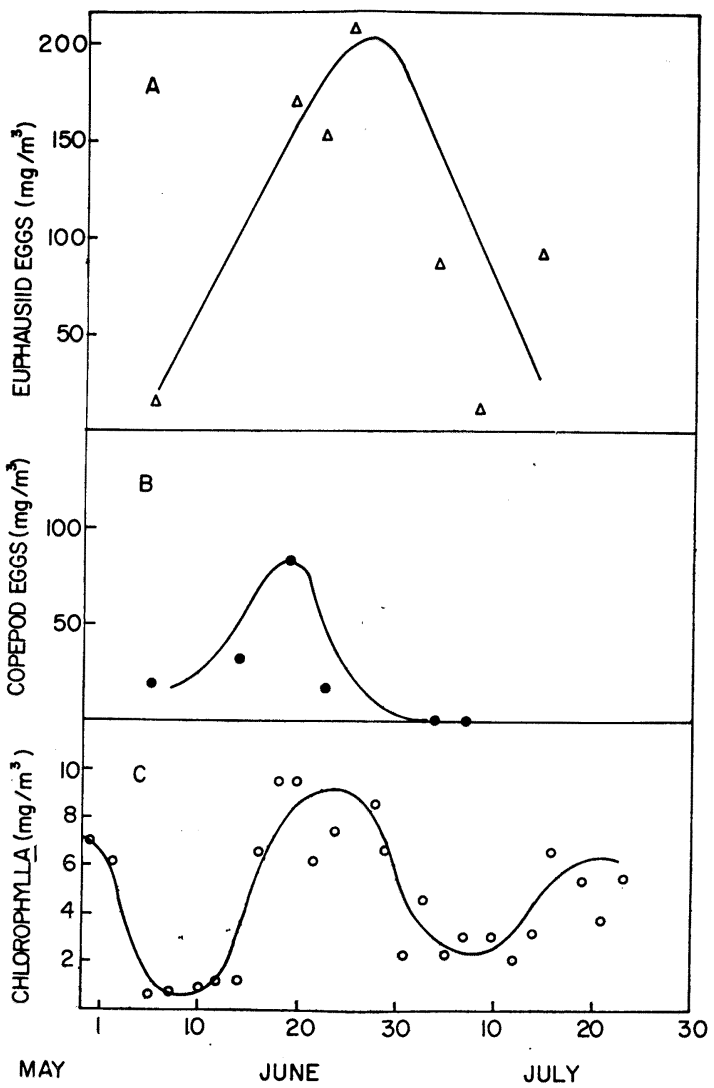

Fig. 1. Changes in the biomass (wet weight average, $0-16 \mathrm{~m}$ ) of euphausiid eggs (A), copepod eggs (B) and chlorophyll $a$ (dry weight) (C), during June and July, 1966, in Saanich Inlet.

the actual biomass of adult euphausiids and copepods was about 5 and $85 \%$ respectively of the total zooplankton. In the following results, data are presented which are descriptive of the relative ability of the various zooplankters present to graze the Chaetoceros and $\mu$-flagellate blooms which occurred during this period. The results obtained provide in part an explanation for the disproportionate egg laying activity of euphausiids and copepods observed during the study period.

Figure 2 shows the effect of Euphausia pacifica grazing on the Chaetoceros bloom. In both figures the size spectrum in terms of biomass of material versus particle diameter is shown before and after grazing. Figure $2 \mathrm{~A}$ and $\mathrm{B}$ represent two of five concentrations of phytoplankton to which euphausiids were added and 


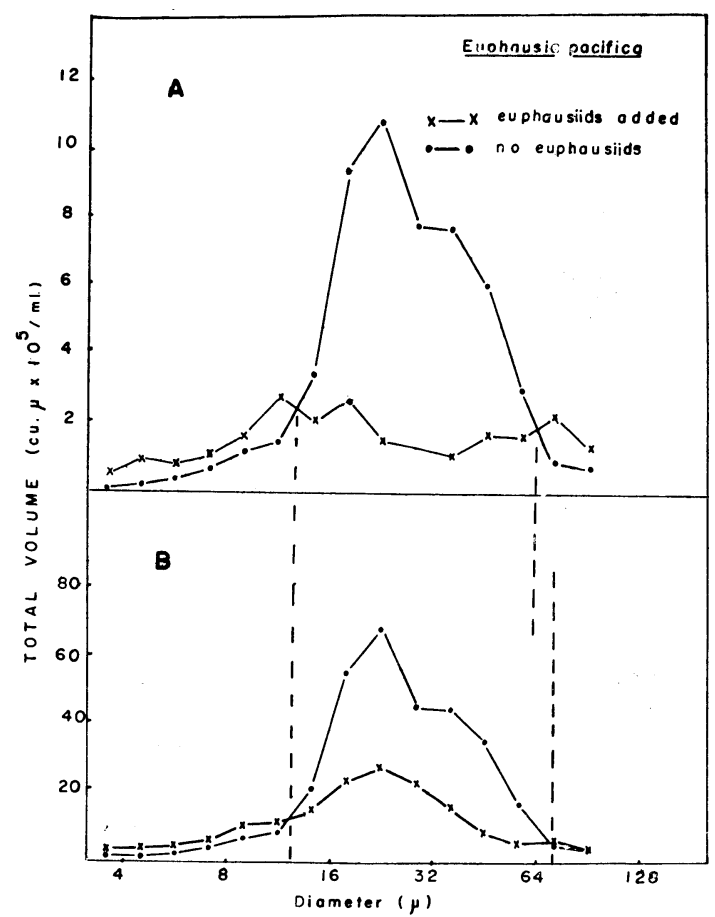

Fig. 2. Size spectrum of particulate material showing the effect of euphausiid grazing at two different concentrations ( $\mathrm{A}$ and $\mathrm{B}$ ) of particles (- - maximum and minimum size fractions grazed).

allowed to graze for eight hours. The concentration of phytoplankton shown in Figure $2 \mathrm{~A}$ was about one-sixth of that shown in Figure 2B. It may be seen that at both concentrations the animals grazed particles down to a size of approximately $12 \mu$; while the upper limit of particle size at which grazing occurred was approximately $64 \mu$ at the lower concentration (A), and about $80 \mu$ at the higher concentration (B). In order to examine the lower size limit of food retention more closely, Euphausia pacifica was fed different concentrations of a second bloom of much smaller phytoplankters. The results of this experiment are shown in Figure 3.

From the inset to Figure 3 it may be seen that the population of phytoplankton was in the nanoplankton size range (size classification of nanoplankton and microplankton have been made following DUSSART, 1965, corrected for a typographical error in the original, DUSSART,

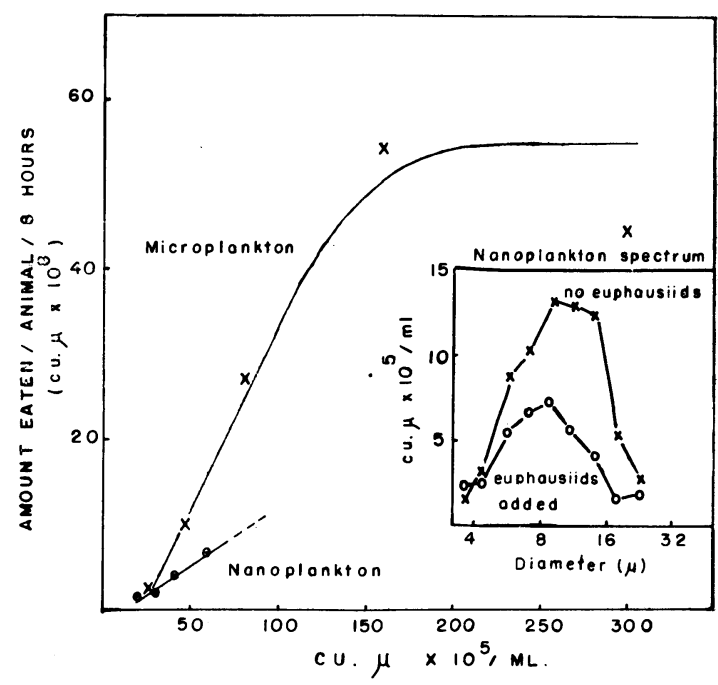

Fig. 3. Quantity of micro- and nanoplankton eaten by Euphausia pacifica at different concentrations. (Inset: Size spectrum of nanoplankton showing effect of euphasiid grazing).

1966, personal communication) and had a mean cell diameter of about $8 \mu$. Effective euphausiid grazing may be seen to have occurred down to a particle size of $5 \mu$ which is considerably lower than the minimum particle size indicated in Figure 2. By plotting the amount eaten at different particle concentrations for the microplankton shown in Figure 2, and the nanoplankton on the inset to Figure 3, it may be seen in Figure 3 that the consumption of nanoplankton is less than the consumption of microplankton per unit increase in plankton concentration, such that at a phytoplankton concentration of $\mathrm{ca} 75 \times 10^{5} \mathrm{cu} \mu / \mathrm{m} l$, approximately twice as much microplankton was consumed. It was not possible to determine the food density at which the euphasiids would have reached their maximum nanoplankton ration ( $R$ in equation (2)) since there was no adequate way of concentrating the nanoplankton. From an approximate extrapolation of the nanoplankton data in Figure 3, however, it appears that the biomass, that would have been necessary for Euphausia pacifica to obtain its maximum ration, would have had to be much greater for nanoplankton than is shown in Figure 3 for microplankton.

In Figure 4 and Table 1 the feeding of 


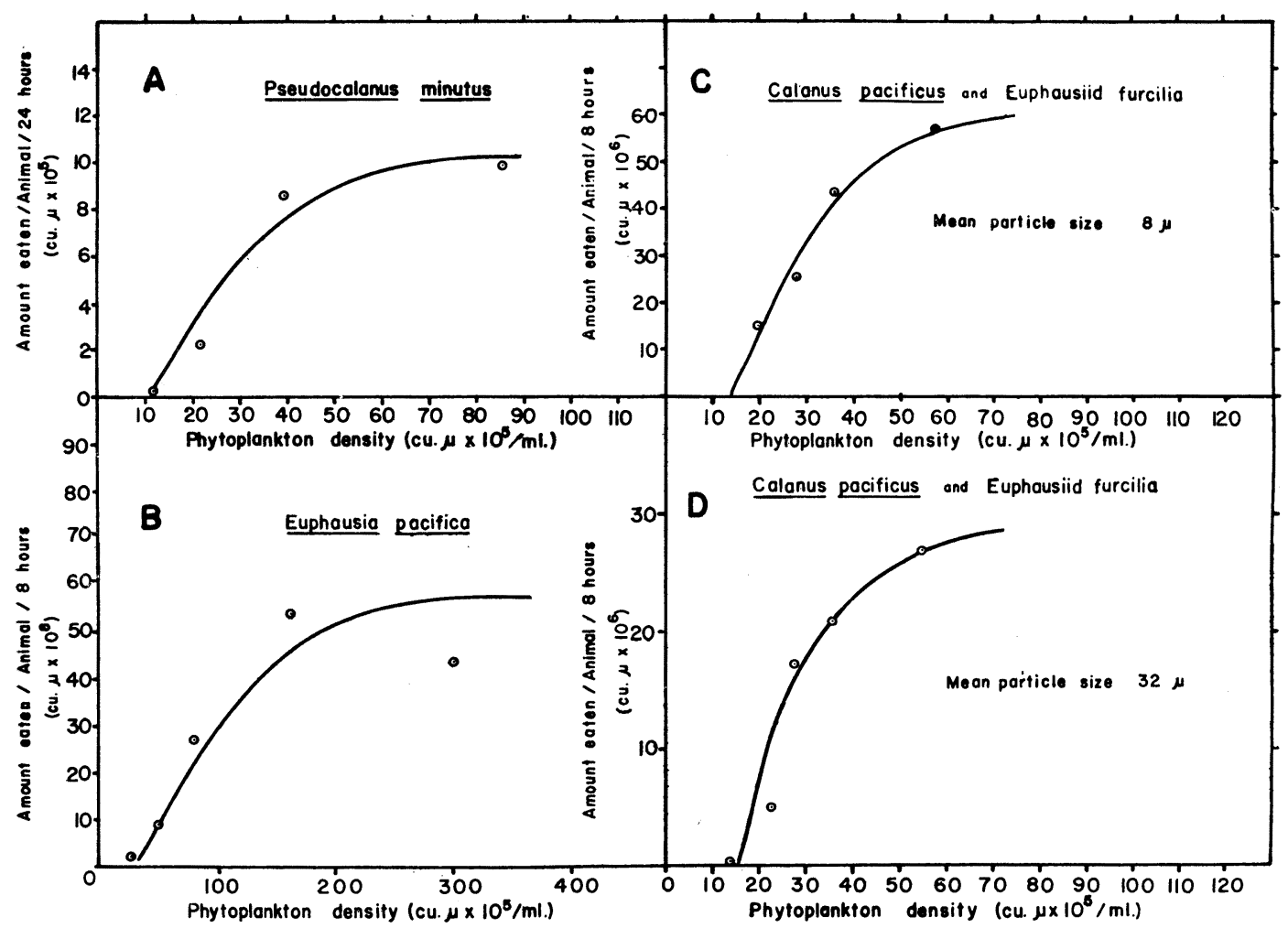

Fig. 4. Quantity of material eaten at different concentrations of phytoplankton. (A) Pseudocalanus minutus and (B) Euphausia pacifica feeding on the microplankton bloom. (C) and (D) a mixture of Calanus pacificus and euphausiid furcilia feeding on nanoplankton and microplankton respectively.

Table 1. Summary of zooplankton grazing experiments.

\begin{tabular}{|c|c|c|c|c|c|c|c|c|c|}
\hline Animal & $\begin{array}{c}\text { Mean } \\
\text { food } \\
\text { size }(\mu)\end{array}$ & $\begin{array}{c}{ }_{\text {Food }} \\
\text { cu } \mu \times \\
\min \\
\left(p_{0}\right)\end{array}$ & $\begin{array}{c}\text { density } \\
10^{5} / \mathrm{m} l \\
\max \\
\left(p_{R}\right)^{x}\end{array}$ & $\begin{array}{r}\text { Food } \\
\mu_{\mathrm{g}} \\
\min _{\left(p_{0}\right)}\end{array}$ & $\begin{array}{l}\text { density } \\
\text { C } / l \\
\max _{\left(p_{R}\right)^{\times}}\end{array}$ & $\begin{array}{c}* 100 \% \text { ration } \\
(R) \text { per } \\
\text { animal/day } \\
(\text { cu } \mu)\end{array}$ & $\begin{array}{c}100 \% \text { ration } \\
(R) \text { per } \\
\text { animal/day } \\
\text { (mg Carbon) }\end{array}$ & $\begin{array}{c}\text { Body } \\
\text { Weight } \\
\text { (mg Carbon) }\end{array}$ & $\begin{array}{c}\text { Ration } \\
\% \\
\text { body wt }\end{array}$ \\
\hline Pseudocalanus minutus & 32 & 11 & 80 & 58 & 420 & $10 \times 10^{5}$ & 0.000052 & 0.0067 & 0.8 \\
\hline Euphausia pacifica & 32 & 25 & 300 & 131 & 1580 & $58 \times 10^{8}$ & 0.302 & 2.02 & 15.0 \\
\hline $\begin{array}{l}\text { Calanus pacificus and } \\
\text { Euphausid furcilia }\end{array}$ & 8 & 14 & 70 & 74 & 365 & $60 \times 10^{6}$ & 0.00312 & 0.0765 & 4.1 \\
\hline $\begin{array}{l}\text { Calanus pacificus and } \\
\text { Euphausiid furcilia }\end{array}$ & 32 & 15 & 70 & 79 & 365 & $29 \times 10^{6}$ & 0.00151 & 0.0765 & 2.0 \\
\hline
\end{tabular}

* Data from Figure $4 .{ }^{\times} p_{R}$, prey density at $100 \%$ ration $(R)$.

Euphausia pacifica is compared with the feeding of other zooplankters on the blooms nano- and microplankton. The feeding of Pseudocalanus minutus on microplankton (Figure 4A) shows that the animal reaches its maximum ration at a microphytoplankton density of about $80 \times 10^{5}$ $\mathrm{cu} \mu / \mathrm{ml}$. In contrast Euphausia pacifica requires about four times this concentration of microphytoplankton in order to reach its maximum ration. The maximum ration of these two organisms, which differ enormously in size, has been compared on the basis of their carbon content in Table 1 . The amount eaten per animal per daily feeding period has been converted to carbon and expressed as a per cent of the average carbon content of each animal. 
From this it may be seen that the maximum ration of carbon taken by Euphausia pacifica per day was $15 \%$ of its body weight while Pseudocalanus minutus only derived $0.8 \%$ of its body weight from the same crop.

Figure 4C shows the result of a zooplankton size fraction containing Calanus pacificus and euphausiid furcilia grazing on different concentrations of the nanoplankton bloom. From this it may be seen that at a phytoplankton density of $70 \times 10^{5} \mathrm{cu} \mu / \mathrm{ml}$ the organisms obtain a maximum ration of about $60 \times 10^{6} \mathrm{cu} \mu /$ animal. With the same animals grazing on the microplankton bloom (Figure 4D) the maximum ration was attained at the same concentration of phytoplankton, but the quantity of plant which the zooplankters were capable of handling was only about half of that which they could consume when feeding on nanoplankton (Figure 4C). This is summarised in Table 1 where it may be seen that the maximum ration obtained by this mixture of zooplankters was about $2 \%$ of their mean body weight when fed on the microplankton bloom but about $4 \%$ when fed on the nanoplankton.

\section{Discussion}

In assessing the relative ability of the three zooplankton size fractions reported here to graze two different blooms of phytoplankton, it should be emphasised that while the phytoplankton were broadly classified into nanoplankton and microplankton on the basis of size, there were also obvious differences in morphology between these two blooms. Species of the genus Chaetoceros have long silicious setae which could physically prevent some herbivores from eating these plants. On the other hand the flagellate, which occurred in the final bloom, may differ in its availability as food from that of a non-motile organism of the same size. The results obtained represent, therefore, a specific examination of the availability of phytoplankton to zooplankton in the area of study. As such, the findings are illustrative of the type of mechanisms involved in the successful growth and reproduction of zooplankters, in so far as these are governed by the availability of food.

In Figure $2 \mathrm{~A}$ and $\mathrm{B}$, it appears that the upper limit of particle size eaten depends on there being a sufficient number of particles for the animals to encounter them as part of their diet. However, since this was a dimictic bloom of similar sized particles the possibility is not excluded that if an appreciably larger organism had been present in sufficient quantities to be repeatedly encountered, it might have been preferentially grazed, as suggested by the work of Mullin (1963). The lower size limit of particles eaten appears (Figure 2) to depend simply on the animal's ability to retain small particles since there was no prey density effect on this value. However this latter assumption does not allow for changes in feeding habits and while the animal may feed raptorially on Chaetoceros chains, filter feeding may play a greater role with smaller food organisms. This has been observed by J $\phi$ RGENSEN (1966) who has suggested that filter feeding generally occurs among adult copepods and euphausiids when particles are less than $50 \mu$ in diameter, but that above $50 \mu$ all herbivorous feeding is raptorial.

In Figure 2 it may be seen in fact that Euphausia pacifica is capable of filtering very small phytoplankton but that it is much less efficient at feeding off these organisms per unit of prey density, than off a larger prey. Similar results were found by RAYMONT and GROSS (1942) in their studies on the feeding of adult Calanus. The authors reported that Calanus was able to survive on very small phytoplankton (1-3 $\mu$ diameter) but that survival was greatly improved by the presence of larger diatoms. The minimum size of particles retained by Euphausia pacifica (Figure 3) is similar to the value of $7 \mu$ reported by BARKLEY (1940) for Euphausia superba.

When a comparison is made between the feeding ability of two zooplankters of different size, it may be seen in Table 1 that the very small zooplankter, Pseudocalanus minutus, was only capable of obtaining $0.8 \%$ of its body weight per day from the Chaetoceros bloom while Euphausia pacifica obtained $15 \%$ of its weight from the same plants. The former value must be considered to be barely a subsistence level of feeding for such a small animal while the latter value would allow for a growth rate of 
about $3 \%$ per day (WINBERG 1956, Table 30). In the case of the euphausiids in situ, the projected weight gain reported here was presumably employed to produce eggs (Figure 1A) while the lack of any large production of copepod eggs (Figure 1B) can in part be attributed to the inability of Pseudocalanus minutus to derive more than a subsistence level of food from the Chaetoceros bloom.

Data on the feeding of a size fraction of zooplankton, intermediate between Euphausia pacifica and Pseudocalanus minutus, are shown in Figure 4C and D, and in Table 1. From these data it may be concluded that the nanoplankton were more acceptable as food than the microplankton but that in both cases neither bloom was a particularly good food source. The fact that the concentration of phytoplankton at which these zooplankters reached their maximum ration was the same for nano- and microplankton (Figure $4 \mathrm{C}$ and $\mathrm{D}$ ) is probably coincidental. In both cases, however, the maximum rations of 2 and $4 \%$ (Table 1) appear to be only subsistence levels of feeding for this size fraction of zooplankton. For these organisms, as well as for Pseudocalanus minutus, it is apparent that the animals were being limited in the quantity of their diet by their lack of ability to efficiently filter the small flagellate or to manipulate Chaetoceros chains. On the other hand the latter appeared to be a good source of food for a large zooplankter, while the former may have constituted a good food source for some animal specially adapted to the filtration of small flagellates.

Another feature of the curves shown in Figure 4 are the intercepts on the $y$-axis which represent the prey density at which the animals ceased to feed ( $p_{0}$ in equation (2)). These values are summarised in Table 1 where it may be seen that the carbon level at which feeding starts is similar for $P$. minutus and the mixture of $C$. pacificus and furcilia, but is rather higher for E. pacifica. However both values are lower than the level of carbon generally found below the euphotic zone in the adjacent waters of the Strait of Georgia. The levels of carbon at which the three groups of animals obtain their maximum ration $\left(p_{R}\right)$ are encountered in the area during phytoplankton blooms when Chlorophyll $a$ values can be as high as $20-30 \mathrm{mg} / \mathrm{m}^{3}$. Data in Figure $1 \mathrm{C}$ were obtained as average values for the depth profile $0-30 \mathrm{~m}$ so that at certain depths the local concentration of plant material was representative of the concentrations required by Euphausia pacifica in order to obtain its maximum ration. A very different situation must exist, however, in the open ocean where concentrations of plant material are at least an order of magnitude lower than in coastal waters. While oceanic species may be capable of obtaining food from lower concentrations of prey, other mechanisms also may play a more important role in feeding in the ocean environment. The aggregation of particulate material along a convergence may provide the necessary concentrations of material or alternatively some species may obtain sufficient food from a larger prey at a lower concentration (i.e. by changing from herbivorous to carnivorous feeding).

Although the curve in Figure $4 \mathrm{~B}$ has been drawn to correspond to equation 2, there is evidence in this experiment that the highest phytoplankton concentrations (i.e. $>250 \times 10^{5} \mathrm{cu}$ $\mu / \mathrm{m} l)$ inhibited the feeding of Euphausia pacifica. Similar results have been found for other zooplankters by several authors among which are Mullin's (1963) observations that increasing concentrations of diatom cells increased the food consumed by Calanus up to a maximum value after which food intake declined. The lack of similar observations in the case of the other zooplankters reported here was probably due to the fact that most of the data were obtained for the other species (Figures $4 \mathrm{~A}, \mathrm{C}$ and $\mathrm{D}$ ) at much lower phytoplankton concentrations.

No evidence for "superfluous feeding" (BEKLEMISHEV, 1957; CUSHING and Vucetic, 1963) was encountered in this series of experiments. However, much of the data presented here are demonstrative of phytoplankton which because of their size or shape were not particularly suited to the zooplankters which were grazing on them. Thus ingestion increased with food concentration up to the point at which the animals were physically unable to cope with any more plant material. This would indicate that superfluous feeding may only be an observable 
Cell Size and Concentrations of Phytoplankton Blooms

phenomenon when plankters are feeding off a particularly convenient size and shape of phytoplankter to which the filtering apparatus of the zooplankter is most naturally suited.

\section{Acknowledgements}

The authors are grateful to the Canadian Navy for the loan of their barge, YBD3, and to Dr. L. Giovando and Mr. C. D. MCAllisteR for assistance in the preparation of this manuscript.

\section{References}

BARKLEY, E. (1940): Nahrung und Filterapparat des Walkrebses Euphasia superba Dana. Z., Fisch. und Hilfswissensch. Beih. 1, Walforsch. 1, 65156.

Beklemishev, K. V. (1957): Superfluous feeding of the zooplankton and the problem of sources of food for bottom animals. Trud. vsesoyuz. gidrobiol. Obsch., 8, 354-358.

Cushing, D. H. (1959): On the nature of production in the sea. Fish. Invest., London Ser. II, 22(6), pp. 40.

Cushing, D. H. and Vucetic, T. (1963): Studies on a Calanus patch. III. The quantity of food eaten by Calanus finmarchicus. J. mar. biol. Ass. U.K. 43, 349-371.

DussarT, B. M. (1965): Les différentes catégories de plancton. Hydrobiologia, 26, 72-74.

Herlinveaux, R. H. (1962): Oceanography of Saanich Inlet in Vancouver Island, British
Columbia. J. Fish. Res. Bd. Canada, 19(1), 137.

IVLEV, V. S. (1945): The biological productivity of waters. Uspekhi Sovremennoi Biologii, 19(1), 98-120.

J $\phi_{\text {RGENSEN, C. B. (1966) : Biology of suspension }}$ feeding. Pergamon Press Ltd., Oxford, pp. 357.

MulliN, M. M. (1963): Some factors affecting the feeding of marine copepods of the genus Calanus. Limnol. Oceanogr., 8, 239-250.

Provasoli, L., Shiraishi, K. and LANCE, J. R. (1959): Nutritional idiosyncrasies of Artemia and Tigriopus in monoxenic culture. Annals N.Y. Acad. Sci. 77, 250-261.

RAymont, J. E. G., and Gross, F. (1942): On the feeding and breeding of Calanus finmarchicus under laboratory conditions. Proc. Roy. Soc. Edinb. B. 61, 267-287.

Sheldon, R. W. and PARsons, T. R. (1966a): On some applications of the Coulter Counter to marine research. Fish. Res. Bd. Canada, MS Rept. (Oceanogr. and Limnol. Ser.), No. 214, pp. 36.

- (1966b): A continuous size spectrum for particulate matter in the sea. J. Fish. Res. Bd. Canada (in press).

WALNE, P. R. (1965): Observations on the influence of food supply and temperature on the feeding and growth of the larvae of Ostrea edulis L. Fish. Invest. London, Ser. II, 24(1), pp. 45.

WinBERG, G. G. (1956): Rate of metabolism and food requirements of fishes. Nauchnye Trudy Belorusskovo Gosudartvennovo Universiteta imeni V. I. Lenina, Minsk, pp. 253, 1956. (Fish. Res. Bd. Canada. Translation Ser. No. 194).

\section{植物プランクトンの細胞の大きさと濃度に依存する 動物プランクトンの食性に関する若干の観察}

\section{T. R. Parsons, R. J. LeBrasseur and J. D. Fulton}

種々の動物プランクトンによって消費される粒子状物 質の量と個々の大きさについて，二つの植物プランクト ンの自然増殖が発生している間に, 研究した。摄取され た粒子状物質の大きさと量は，B 型コウルター・カウン ターで測定した. この結果, Euphausia pacifica は Chaetoceros 群を進んで摄取するが，おきあみ類のファ ーシリア期幼生や Pseudocalanus minutus は, この植 物群から必要最小限の食糧しか得られないということが 示された. Chaetoceros 群とは対照的に, 微細プランク
トン（直経約 $8 \mu ）$ は Euphausia pacifica には食物と してほとんど利用されないが，Calanus pacificus とフ アーシリア期幼生にとっては，よりよい食糧源になるこ とが判明した．この相違は，大きさや形によって食物と して利用する能力に原因がある.

種々の植物プランクトン濃度での動物プランクトン食 性に関するデータは, プランクトン食魚類に対して IVLEV（1945）が出した濃度と食性との依存関係と同様 な関係を仮定すると，よく説明される. 